\title{
Effect of Jigsaw Co-Operative Learning Method in Improving Cognitive Skills among Medical Students
}

\section{C.S. Vinod Kumar ${ }^{1}$, Suneeta Kalasuramath ${ }^{2}$, Satish Patil ${ }^{1}$, K.G. Raghu Kumar1, K.R. Shama Taj ${ }^{1}$, V.L. Jayasimha ${ }^{1}$, K.G. Basavarajappa ${ }^{1}$, P. Shashikala ${ }^{3}$, Anand Kukkamalla ${ }^{4}$ and Thomas Chacko ${ }^{5}$}

${ }^{1}$ Department of Microbiology, ${ }^{2}$ Department of Physiology, ${ }^{3}$ Department of Pathology, S. S. Institute of Medical Sciences and Research Centre, NH-4, Bypass road, Davangere-577005, Karnataka, India

${ }^{4}$ Department of Microbiology, Melaka Manipal Medical College, Manipal University, Karnataka, India

${ }^{5}$ Director, PSG-FAIMER Regional Institute, PSG IMSR, Coimbatore, India

*Corresponding author

\begin{tabular}{|c|c|}
\hline & A B S T R A C T \\
\hline & $\begin{array}{l}\text { To shift the paradigm from a passive tutor driven tutorials to more responsible active } \\
\text { learning by the students, a cooperative teaching learning method could be a good }\end{array}$ \\
\hline Keywords & $\begin{array}{l}\text { alternative. The Jigsaw approach, a model of co-operative learning, focuses on } \\
\text { learning in groups with fellow learner co-operation and reassures team work. Thus, }\end{array}$ \\
\hline $\begin{array}{l}\text { Cooperative } \\
\text { teaching learning, }\end{array}$ & $\begin{array}{l}\text { this study was aimed at assessing the effectiveness of jigsaw strategy in comparison to } \\
\text { tutorials in enhancing cognitive skills among the medical students in microbiology. A }\end{array}$ \\
\hline Jigsaw, Tutorial, & cross sectional study was carried out at microbiology department for 50 consenting \\
\hline $\begin{array}{l}\text { Post-test, Absolute } \\
\text { achievement level, } \\
\text { Retention test, } \\
\text { Effect size. }\end{array}$ & $\begin{array}{l}\text { MBBS phase II students. Students were randomly divided into two groups A and B of } \\
25 \text { students each. They were prepared for either a jigsaw (Experimental) or tutorial } \\
\text { (Control) a week prior on pre-decided topics. The same groups were crossed over for } \\
\text { another topic. Students performance was assessed by pretest, posttest, and academic }\end{array}$ \\
\hline Article Info & achievement level and retention test by pre-validated multiple choice questionnaires. \\
\hline $\begin{array}{l}\text { Accepted: } \\
\text { 08 February } 2017 \\
\text { Available Online: } \\
10 \text { March } 2017\end{array}$ & $\begin{array}{l}\text { questionnaires. Post test scores of both groups was found to be significant at the level } \\
\text { of } \mathrm{P}<0.05 \text {. Mean of post test scores in the jigsaw is more than tutorial }(12.4 \mathrm{v} / \mathrm{s} 9.7 \text {, } \\
\text { crossover } 13.3 \mathrm{v} / \mathrm{s} 11.2) \text {. Mean retention tests scores and absolute achievement level } \\
\text { were high in jigsaw groups. The students preferred jigsaw over the tutorial. Jigsaw }\end{array}$ \\
\hline & $\begin{array}{l}\text { strategy is a robust instructional tool, well perceived by the students to enhance } \\
\text { cognitive skills as inferred by the results and can be tailored to the needs of varied } \\
\text { topics across different disciplines. }\end{array}$ \\
\hline
\end{tabular}

\section{Introduction}

There is growing concern among medical educators that conventional modes of teaching medical students neither encourage the right qualities in students nor impart a life-long 
respect for learning. The organization of a general classroom education is mainly classified into three main forms: competitive, individualistic, and cooperative (Mergendoller, 1989). Competitive classrooms are based on the concept of ranking. Performance indicators such as grades are used to differentiate among individual students. Only one student can be at the top. For one's success, failures of others are necessary. Medical schools are a classic example where this environment is found (Buhr, 2014). Standards for success are clearly communicated in an individualistic classroom. Success or failure of any one student depends on that student's individual actions. There is no connection of one student's success or failure to any other student's success or failure. It is possible for two or more students to be on top of the class. Many high schools use this approach for calculating standing in the graduating class (Johnson and Johnson, 2009).

The cooperative classroom is based on the group success. There is no way one can succeed if the other in the group fails. "Cooperative learning refers to methods of instruction that organize classroom instruction so that groups of 2-6 students work together to reach a common goal. Cooperative learning involves all group members who share in process, content, and accountability (Hanze, 2007). Many researchers have affirmed that when the focus shifts from the individual to the group, individual learning is enhanced, not diminished (Marzano, 2003; GonzalezRothi, 2015; Slavin, 1995, 1996).

The Jigsaw learning style is one of the most popular and commonly adopted models of cooperative learning (Slavin, 2011). The jigsaw strategy serves several purposes in the learning process. The primary purpose of the strategy is to facilitate learning in groups, with co-operation from fellow learners and to encourage team work, ultimately enhancing the teaching-learning experience. The present study was taken with an objective to study the effect of jigsaw versus the conventional tutorial $\mathrm{T} / \mathrm{L}$ methods in enhancing cognitive skills in microbiology and to assess the student perception towards cooperative group activities

\section{Materials and Methods}

\section{Null hypotheses}

The Jigsaw cooperative learning method (students working together in organized groups to attain shared learning objectives; team member must be responsible for their own learning and for the success of other team members' learning) is not expected to help students achieve greater academic benefits in terms of gain in post test scores and greater retention of knowledge than those taught through tutor based teaching.

\section{Study type}

A randomized crossover groups study.

\section{Method}

The study commenced after obtaining the ethical clearance from the Institutional Ethics Review Board, S. S. Institute of Medical Sciences and Research Centre.

The students after consenting to the study were divided into batches $\mathrm{A}$ and $\mathrm{B}$ each of 25 students.

For the first week of the study the batch A were informed to come prepared for a conventional tutorial on the pre-decided topic, while the batch B would be prepared for the jigsaw strategy (Sagsoz, 2015; Slavin, 1996).

In the control group, students learned the content of the pre-decided topic as a result of lecture-based teaching in logical steps, and 
they worked as a whole class group, with some time spent on questions and general class discussions. The instructor's role was one of information transmitter. The main interaction was to be between the teacher and the students. In the experimental group, the instructor applied the jigsaw technique, which was framed around a given pre-decided topic same as for control group. In Jigsaw group (Experimental) students were divided into 5 groups with 5 members in each group (expert group). Each group member is responsible for learning a part of the overall 'puzzle (topic)'. The students were given one week time to read and prepare handouts on the topic allotted to them. The handouts prepared by the students were based on the common question sheet provided by the subject experts.

The subject expert monitored the preparation of the students and gave the inputs when felt necessary to maintain the uniformity in the preparation. On the day of the learning activity, students were regrouped such that each new group now called the teaching group (home group) will have one member from the expert group who have prepared a different part of the puzzle (topic) (GonzalezRothi, 2015). Each student teaches his peers the part they have prepared. The topic is structured so that the only access to the other parts of the puzzle is through the other group members. During the student's group teaching activity, the observer monitored the activity to prevent discussions going astray. The detailed activities are depicted in table 1 .

After the groups completed their discussions in the specified time, a case scenario was presented one to each teaching group based on the topic discussed which has to be solved in the group. Later after the completion of this task all groups assemble in one classroom to discuss all the problems which completes the jigsaw puzzle.

\section{Crossover study}

The two groups were crossed over to minimise the bias. The 25 students who were in control group were crossed to experimental group and the students who were in experimental group were crossed to control group. The students were asked to come prepared on another topic in microbiology. The rest of the methodology and the assessment were same as explained above.

\section{Instrumentation}

Pre-test questions were developed and validated. All questions focused on the students' knowledge of topic discussed. A post-test also comprised 15 questions and used to measure achievement immediately after the intervention ended. A delay test questionnaire (the same as the post-test) was used to measure the percentage of scores the students realized after one month. All questions in both pre-test and post-test were presented in a multiple-choice format. Each question had three alternative choices for the correct answer.

The instrument was validated by four experts in education research at the institute to assess the content, construct and face validity. This showed that the items in the instrument were precise and comprehensive enough to provide to the anticipated type of data and also determined that the research objective was achieved (Mugenda and Mugenda, 1999).

Reliability of the instrument was estimated using Cronbach's coefficient alpha, which is suitable when items are not dichotomously scored (Gall, Gall and Borg, 2003; Frankel and Wallen, 2003; Gay and Airasian, 2003). The result of the reliability estimate of the questionnaires was obtained as 0.87. The instrument met the threshold reliability coefficient of 0.70 and higher which is recommended (Gall et al., 2003; Frankel and 
Wallen, 2003; Mugenda and Mugenda, 1999). Feedback questionnaire was administered to both the experimental and control groups after the intervention as part of this study to measure students' perception of the instructor and instructions regarding the process. It was used to validate the fact that there was a difference in treatment as planned (Marzano, 2001).

This survey, containing 15 items, measured a range of elements of the instructor and the instruction offered to students in both the groups. Of these items, there were some which were meant to be equally applicable to the instructor and instructions in both groups, and others which focused on the extent to which students experienced techniques associated will cooperative group-work.

\section{Data analysis}

The software that was used for data analysis was the SPSS. The scores obtained from pretest and post-test for experimental group was compared in terms of mean scores and standard deviation. Paired samples t-test at coefficient alpha level of 0.05 was used in order to find out whether there was any significant difference before and after the implementation of Jigsaw cooperative learning in the microbiology topics.

\section{Results and Discussion}

\section{Pre- test analysis}

The findings of the ANOVA analysis show no statistically significant difference in microbiology pretest scores between the control group and experimental group $(t=1.163)$. These results reveal that the students in both the groups had similar academic knowledge on the microbiology before the intervention commenced (Table 2). The results of the pretest were also same in the crossover group.

\section{Effects of the Jigsaw learning strategy on the students' achievement}

As for the academic achievement of post-test scores of both the groups, $t$ value appears to be 6.457 and found to be significant at the level of $\mathrm{p}<0.05$. The magnitude of the difference in the mean was large. The mean of post-test scores in the Jigsaw group is 12.4 which is significantly bigger than the mean of post-test scores in the control group (Mean=9.7). The finding showed that the experimental group which had engaged in cooperative learning produced higher overall improvement in post test scores on the microbiology topic (Table 2).

In the crossover group study, the posttest score in the jigsaw was significant when compared to the control group indicating jigsaw helped in enhancing the knowledge (Table 3).

\section{Knowledge retention analysis}

Findings of the t-test analysis on the microbiology delay test scores showed significant difference between experimental group and the control group in before and after the crossover. The results highlights jigsaw learning helped the students to retain knowledge and produced a higher overall improvement in the scores on the delay test scores (Table 4).

\section{Absolute achievement level}

According to these findings, mean scores of both experimental and control group students increased. When considered in terms of absolute achievement level, experimental group students were found to achieve $69.1 \%$ of the target in the pre-test, $88.6 \%$ of the target in the posttest and $84.2 \%$ of the target in the retention test (Table 4). 
Table.1 Detailed activities for Jigsaw

\begin{tabular}{|c|c|c|c|}
\hline SI no & Activity & Teaching aid & Duration \\
\hline 1 & Attendance, pre-test & Audio-video aid & $\begin{array}{l}15 \\
\text { minutes }\end{array}$ \\
\hline 2 & Instructions to jigsaw groups & Audio aid & $\begin{array}{l}5 \\
\text { minutes }\end{array}$ \\
\hline 3 & $\begin{array}{l}\text { Regrouping of expert groups into teaching } \\
\text { groups (home group) }\end{array}$ & Audio aid & $\begin{array}{l}5 \\
\text { minutes }\end{array}$ \\
\hline 4 & $\begin{array}{l}\text { Intra-group discussion for } 1^{\text {st }} \text { specific learning } \\
\text { objective (one students presents to the rest } 4 \text { in } \\
\text { one group) under observation of facilitator }\end{array}$ & $\begin{array}{l}\text { Hand-outs prepared } \\
\text { by the students }\end{array}$ & 6 \\
\hline 5 & $\begin{array}{l}\text { Intra-group discussion for } 2^{\text {nd }} \text { specific learning } \\
\text { objective (one students presents to the rest } 4 \text { in } \\
\text { one group) under observation of facilitator }\end{array}$ & $\begin{array}{l}\text { Hand- outs prepared } \\
\text { by the students }\end{array}$ & 6 \\
\hline 6 & $\begin{array}{l}\text { Intra-group discussion for } 3^{\text {rd }} \text { specific learning } \\
\text { objective (one students presents to the rest } 4 \text { in } \\
\text { one group) under observation of facilitator }\end{array}$ & $\begin{array}{l}\text { Hand-outs prepared } \\
\text { by the students }\end{array}$ & 6 \\
\hline 7 & $\begin{array}{l}\text { Intra-group discussion for } 4^{\text {th }} \text { specific learning } \\
\text { objective (one students presents to the rest } 4 \text { in } \\
\text { one group) under observation of facilitator }\end{array}$ & $\begin{array}{l}\text { Hand-outs prepared } \\
\text { by the students }\end{array}$ & 6 \\
\hline 8 & $\begin{array}{l}\text { Intra-group discussion for } 5^{\text {th }} \text { specific learning } \\
\text { objective (one students presents to the rest } 4 \text { in } \\
\text { one group) under observation of facilitator }\end{array}$ & $\begin{array}{l}\text { Hand-outs prepared } \\
\text { by the students }\end{array}$ & 6 \\
\hline 9 & Case scenario discussion by the groups & & $\begin{array}{l}6 \\
\text { minutes }\end{array}$ \\
\hline 10 & Overall summary by the staff & Audio aid & $\begin{array}{l}10 \\
\text { minutes }\end{array}$ \\
\hline 11 & Post-test & Audio-video aid & $\begin{array}{l}10 \\
\text { minutes }\end{array}$ \\
\hline 12 & Feed-back by students & Pre-validated & $\begin{array}{l}5 \\
\text { minutes }\end{array}$ \\
\hline \multicolumn{3}{|c|}{ Total duration adds up to } & $\begin{array}{l}80 \\
\text { minutes }\end{array}$ \\
\hline
\end{tabular}

Table.2 Effect of Jigsaw vs. tutorial TL methods in improving the cognitive skills

\begin{tabular}{lllllcc}
\hline & Groups & Mean \pm SD & SD & t & P value & Effect size \\
\hline Pre-test & Tutorial (N=25) & $8.7(68.3)^{*}$ & 2.0 & \multirow{2}{*}{1.1630} & \multirow{2}{*}{0.231} & \multirow{2}{*}{0.51} \\
& Jigsaw (N=25) & $8.0(69.1)$ & 1.5 & & & \\
Post test & Tutorial (N=25) & $9.7(79.4)$ & 1.9 & \multirow{2}{*}{6.4579} & 0.000 & \multirow{2}{*}{3.38} \\
& Jigsaw (N=25) & $12.4(88.6)$ & 1.1 & & & \\
\hline
\end{tabular}

* Absolute achievement level 
Table.3 Effect of Jigsaw vs. tutorial TL methods in improving the cognitive skills among the cross over group

\begin{tabular}{|c|c|c|c|c|c|c|}
\hline & Groups & Mean \pm SD & SD & $\mathrm{t}$ & $\mathrm{P}$ value & Effect size \\
\hline \multirow[t]{2}{*}{ Pre-test } & Tutorial $(\mathrm{N}=25)$ & $9.5(72.2)^{*}$ & 1.6 & \multirow{2}{*}{0.7194} & \multirow{2}{*}{0.54} & \multirow{2}{*}{1.09} \\
\hline & Jigsaw (N=25) & 9.8 (71.7) & 1.3 & & & \\
\hline \multirow[t]{2}{*}{ Post test } & Tutorial $(\mathrm{N}=25)$ & $11.2(76.1)$ & 1.5 & \multirow{2}{*}{5.5292} & \multirow{2}{*}{0.000} & \multirow{2}{*}{1.94} \\
\hline & Jigsaw $(\mathrm{N}=25)$ & $13.3(94.5)$ & 1.8 & & & \\
\hline
\end{tabular}

* Absolute achievement level

Table.4 Retention scores among the jigsaw and tutorial groups

\begin{tabular}{llllcc}
\hline & Groups & Mean \pm SD & SD & P value & Effect size \\
\hline First & Tutorial (N=25) & $6.7(62.4)^{*}$ & 0.8 & \multirow{2}{*}{0.00} & 5.51 \\
& Jigsaw (N=25) & $11.2(84.2)$ & 1.6 & & \\
Crossover & Tutorial (N=25) & $7.0(64.3)$ & 1.0 & \multirow{2}{*}{0.000} & 5.19 \\
& Jigsaw (N=25) & $12.8(88.5)$ & 1.8 & & \\
\hline
\end{tabular}

* Absolute achievement level

Table.5 Students' feedback on the teaching and learning process

\begin{tabular}{|c|c|c|c|c|c|c|}
\hline & \multicolumn{3}{|c|}{ Jigsaw } & \multicolumn{3}{|c|}{ Tutorial } \\
\hline & Agree & $\begin{array}{l}\text { Partially } \\
\text { agree }\end{array}$ & $\begin{array}{l}\text { Don't } \\
\text { agree }\end{array}$ & Agree & $\begin{array}{l}\text { Partially } \\
\text { agree }\end{array}$ & Don't agree \\
\hline $\begin{array}{l}\text { Preparing before the TL } \\
\text { method stimulated interest }\end{array}$ & 84 & 12 & 4 & 46 & 40 & 14 \\
\hline $\begin{array}{l}\text { Helped in understanding the } \\
\text { topic in a sequential orderly } \\
\text { manner }\end{array}$ & 88 & 12 & 0 & 22 & 36 & 42 \\
\hline $\begin{array}{l}\text { The TL method guided me to } \\
\text { take responsibility of my } \\
\text { learning }\end{array}$ & 96 & 4 & 0 & 14 & 8 & 78 \\
\hline $\begin{array}{l}\text { Enjoyed team work and also } \\
\text { individual presentations in the } \\
\text { group }\end{array}$ & 86 & 12 & 2 & 4 & 12 & 84 \\
\hline $\begin{array}{l}\text { The handouts prepared helped } \\
\text { me during discussion and for } \\
\text { future reading }\end{array}$ & 92 & 8 & 0 & 0 & 4 & 96 \\
\hline $\begin{array}{l}\text { Team members support to } \\
\text { build up the answers to } \\
\text { questions }\end{array}$ & 76 & 20 & 4 & 4 & 10 & 86 \\
\hline $\begin{array}{l}\text { Promoted critical thinking and } \\
\text { decision making }\end{array}$ & 80 & 14 & 6 & 20 & 14 & 66 \\
\hline $\begin{array}{l}\text { Enjoyable learning experience } \\
\text { with my peers }\end{array}$ & 84 & 14 & 2 & 8 & 12 & 80 \\
\hline $\begin{array}{l}\text { Preparing for the TL method } \\
\text { was time consuming }\end{array}$ & 6 & 34 & 60 & 40 & 44 & 16 \\
\hline $\begin{array}{l}\text { Helpful in developing my } \\
\text { information synthesizing skills }\end{array}$ & 82 & 16 & 2 & 22 & 16 & 62 \\
\hline
\end{tabular}


In control group, students were recorded to achieve $68.3,79.4$ and $62.4 \%$ of the target in the pre-test, post test and retention-test, respectively (Table 4). Similarly in case of crossover batch, the absolute achievement levels were high in jigsaw group compared to the tutorial group.

\section{Feedback}

Students' views about Jigsaw technique were conducted with experimental group's students to obtain their ideas about Jigsaw and they were recorded, $88 \%$ of the students indicated that Jigsaw increased their achievement, helped in understanding the topic better and made the subject easier, $84 \%$ opinion jigsaw helped in taking responsibility of learning and $76 \%$ said they enjoyed learning experience with their peers and $72 \%$ agreed that team members supported their learningthrough different angles, group members clarified the topic with original examples, permanently acquired knowledge, enhanced selfconfidence, improved cooperation and interaction, provided active participation and arose the aim of reaching knowledge (Table 5).

Twenty two per cent of the students pointed that the jigsaw preparation is time consuming and $12 \%$ emphasized a preference of teacher instruction instead of group working and few pointed that students whose performance was lower, slowed down the success of other students.

In recent years teaching and learning methods have moved much higher up the agenda within institutions of higher education. No discussion of teaching methods makes much sense without prior consideration of what we are trying to achieve with the teaching methods. "Teaching methods" are not an end in themselves, they are a means to an end. They are the vehicle(s) we use to lead our students towards particular learning outcomes. There is a shift from the 'teacher as expert' role in which more didactic teaching methods were used, to 'teacher as facilitator of learning' in which teachers guide learners towards resources and sources of knowledge just as much as being the sources of knowledge themselves (Slavin, 1996).

Eliot Aronson in 1978 developed Jigsaw to improve the collaboration of students that includes two different actions of small groups (Hedeen, 2003). Jigsaw has undergone changes in the techniques, the implementation phase has been modified and this has led to diverse types of jigsaw. Jigsaw I, Jigsaw-II (Slavin, 1987), Jigsaw-III (by Stahl, 1984), Jigsaw-IV (Holliday, 2000), Reverse Jigsaw (Heeden, 2003) and Subject Jigsaw (Doymus, 2007) have been developed. The jigsaw technique can enhance cooperative learning by making each student responsible for teaching some of the materials to the group. In this technique, students are members of two different groups, the "home group" and the "jigsaw group." Initially, students meet in their home groups, and each member of the home group is assigned a portion of the material to learn as an "expert" (Doymus et al., 2004; Slavin, 1991). Jigsaw IV technique appears to be more developed for complete learning compared to other Jigsaw techniques (I-II-III). In Jigsaw IV, the students in the expert groups are assessed to check for their preparation. According to results, the missing parts of the learning are determined and completed. The same implementation is repeated to the actual group members after the expert members carry out their subject presentation in the actual groups.

It has been observed that students who learnt microbiology through the Jigsaw cooperative learning approach performed significantly better than those who were educated through the conventional teaching methods. These 
findings corroborate with earlier studies where the authors emphasized that the use of the Jigsaw cooperative learning tool improved achievement scores compared to the conventional teaching methods (Sagsoz, 2015, Hanze and Berger, 2007, Kiliac, 2008). The results further approve Burns (1984) statement that Jigsaw cooperative learning strategy results in higher learners achievement because they engage in thoughtprovoking tasks in their expert groups with eagerness because they know they have to teach the content assigned to them when they move back to their corresponding home groups. Students helped one another in the learning process and it was the responsibility of each member in a group to make sure that other group members had mastered the concepts learnt in expert groups. The high performers and low performers learnt together because the activities demanded teamwork to accomplish. The Jigsaw cooperative learning makes learning interesting, highly cooperating, students actively learn, and encourages student's accountability in learning (Baird and White, 1984). This is necessary in order for them to develop a variety of problem solving techniques and to convert what they have learnt for better use.

Scientists have studied the effectiveness of cooperative learning as an instructional tool by generally focusing on short-term learning outcomes such as test performance. In this study we measured the longer term impact of cooperative learning on the development of need for cognition. The retention test result showed significant difference between jigsaw groups and the traditional teaching method. Jigsaw groups were involved with higher participation in the process of learning, had greater long-term achievement on the microbiology delay test than students in the control group because jigsaw groups were equipped with skills in terms of teaching others and expounding ideas on the concept imparted in the learning process. This finding confirms the results of some earlier studies (Johnson and Johnson, 2005; Tanel and Erol, 2008; Moore, 2008; Sahin, 2010) which substantiates that jigsaw learning promotes greater long-term achievement than individual learning. This study further emphasizes that learning activities based on distributed learning tasks, along with the students' special involvement in the learning process, contributed to their improvement in the scores on the delay test in the jigsaw group. The results of this study are concurrent with the results of the previous studies (Slavin, 2011; Sahin, 2010; Johnson and Johnson, 2008; Tanel and Erol, 2008; Webb, 2008; Moore, 2008) that specify that cooperative learning results in greater long-term achievement than the traditional lecture-based teaching group.

Cooperative learning strategies might be an effective teaching tool for those who wish to develop long-term student interest in cognition (Slavin, 1995). Faculty members should be cautioned that cooperative learning must be administered appropriately, focusing on interdependence among group members. In some classrooms, instructors assign students to work in groups, without significant oversight of group dynamics and group member responsibility. Faculty tends to treat college students as adults, allowing groups to divide the work evenly and compile the individual efforts rather than working interdependently. For cooperative learning to be effective, students should rely on each other, with the understanding that each individual is required to contribute toward overall group success. Students who engage in cooperative learning build trust and develop commitment to other group members.

MCI vision 2015 envisages that the Indian Medical Graduates will have the necessary competencies (Knowledge, Skills and Attitudes) to assume his or her role as health care providers. Hence the modifications have been made in the existing curricula to 
accommodate the aspirations of the defined goals, competencies and greater emphasis on co-operative learning.

The effectiveness of the new training program was done using the Kirkpatrick's model of training program evaluation. Student feedback about the process revealed that a large majority of students showed acceptance of the innovative method, agreed about perceived practicability and potential in application of what was learnt after using the jigsaw technique (Kirkpatrick's level I: Student Reaction). Post-test assessment of knowledge showed substantial increase in post-test scores demonstrating that the students learnt what was intended to learn and later on in the retention test revealed noticeable retention in knowledge among the students (Kirkpatrick's level II: Learning). The evaluation of the Jigsaw method of teaching by Kirkpatrick evaluation framework suggests that Jigsaw is an effective teaching-learning tool and has an impact on the learning outcome among the students and is acceptable to them.

The cooperative structure in this study resulted in better achievement in the microbiology topics than the competitive and individualistic structures found in traditional classrooms because students construct or build their own concepts and then reinforce them with one another. Though active cooperative $\mathrm{T} / \mathrm{L}$ methods are time consuming in terms of planning and execution but are very effective in bringing out operational outcome for students and faculty. It would be desirable therefore to implement this strategy at least for few selected topics as mentioned by the students in the feedback.

\section{Acknowledgement}

Authors would like to thank PSG-FAIMER Regional Institute, PSG IMSR, Coimbatore, India for the opportunity and S.S. Institute of
Medical Sciences and Research Centre, Davangere, Karnataka, India for the facilities.

\section{References}

Baird, J., White, R. 1984. Improving learning through enhanced metacognition: A classroom study. Paper presented at the annual meeting of the American Educational Research Association, New Orleans, LA 1984

Buhr, G.T., Heflin, M.T., White, H.K., Pinheiro, S.O. 2014. Using the jigsaw cooperative learning method to teach medical students about long-term and postacute care. J. Am. Med. Dir. Assoc., 15(6): 429-34.

Burns, M. 1984. The Math Solution. Marilyn Burns Education Associates publishers, reprinted in "Cooperative Learning in Mathematics" Neil Davidson editor, 1990.

Coolican, H. 1994. Research Methods in Psychology, (2nd ed. London: Hodder and Sloughlon Education.

Doymus, K. 2007. The effect of a cooperative learning strategy in the teaching of phase and one-component phase diagrams. $J$. Chem. Educ., 84(11): 1857-1860.

Frankel, J.R and Wallen, N.E. 2003. How to Design and Evaluate Research in Education, Newyork, NY: McGraw-hill Company Inc.

Gall, M.D., Gall, J.P. and Borg, W.R. 2003. Education Research: An Introduction (7th ed) Newyork: Person Education Inc.

Gay, L.R., and Airasian, P. 2003. Educational research: Competencies for analysis and application (7th ed. Upper Saddle River, NJ: Pearson Education.

Gonzalez-Rothi, R., Alexandraki, I. Using jigsaw learning methodology to foster active learning about pulmonary infections. Med Ed PORTAL Publications, 11: 10188.

Hanze, M., and Berger, R. 2007. Cooperative learning, motivational effects, and student characteristics: An experimental study comparing cooperative learning and direct instruction in 12th grade physics classes. Learning and Instruction, 17, 29-41.

Hedeen, T. 2003. The Reverse Jigsaw: A process of cooperative learning and discussion. Teach. Sociol., 31(3): 325-332. 
Holliday, D.C. 2000. The development of jigsaw in a secondary social studies classroom. Paper presented at the 2000 Midwest Educational Research Association (MWERA) Annual Conference in Chicago, IL.

Johnson, D.W., and Johnson, R.T. 2009. An Educational Psychology Success Story: Social Interdependence Theory and Cooperative Learning. Educational Researcher, 38(5): 365-379.

Kilic, D. 2008. The Effects of the Jigsaw Technique on Learning the Concepts of the Principles and Methods of Teaching, World Appl. Sci. J., 4: 109-114.

Marzano, R.J. 2003. What works in schools: Translating research into action, Alexandria, VA: Association for Supervision and Curriculum Development.

Marzano, R.J., Pickering, D.J., and Pollock, J.E. 2001.Classroom Instruction That Works: Research-Based Strategies for Increasing Student Achievement. Alexandria, VA: The Association for Supervision and Curriculum Development (ASCD) Medical Council of India Vision 2015.

Mergendoller, J., Packer, M.J. 1989. Cooperative learning in the classroom: A knowledge brief on effective teaching, San Francisco: Far West Laboratory.

Moore, K.D. 2008. Effective instructional strategies: From theory to practice. Thousand Oaks, CA: Sage Publications.

Mugenda, M.O. and Mugenda, A.G. 1999. Research methods. Qualitative and quantitative approaches, Nairobi, Kenya: CTS Press.

Sagsoz, O., Karatas, O., Turel, V., Yildiz, M., Kaya. 2015. Effectiveness of Jigsaw learning compared to lecture-based learning in dental education. Eur. J. Dental Education, DOI: 10.1111/eje.12174

Sahin, A. 2010. Effects of Jigsaw III technique on achievement in written expression.Asia Pacific Educ. Rev, Education Research Institute, Seoul National University, Seoul, Korea.

Slavin, R.E. 1995.Cooperative learning $\left(2^{\text {nd }} \mathrm{ed}\right.$. Boston: Allyn.

Slavin, R.E. 1996. Research on co-operative learning and achievement: What we know, what we need to know. Contemporary Educational Psychol., 21: 43-69.

Slavin, R.E. 2011. Instruction Based on Cooperative Learning. In R. E. Mayer and P. A. Alexander (Eds.), Handbook of Research on Learning and Instruction (pp. 344-360. New York: Taylor and Francis.

Stahl, R. Ed. 1994. Cooperative learning in social studies: A handbook for teachers. Menlo Park, CA: Addison-Wesley.

Tanel, Z., and Erol, M. 2008. Effects of Cooperative Learning on Instructing Magnetism: Analysis of an Experimental Teaching Sequence. American J. Physics and Edu., 2(2): 124-136.

Webb, N.M. 2008. Learning in small groups. In T. L. Good (Ed.), 21st Century education: A reference handbook (pp. 203-211. Los Angeles: Sage.

\section{How to cite this article:}

Vinod Kumar, C.S., Suneeta Kalasuramath, Satish Patil, K.G. Raghu Kumar, K.R. Shama Taj, V.L. Jayasimha, K.G. Basavarajappa, P. Shashikala, Anand Kukkamalla and Thomas Chacko. 2017. Effect of Jigsaw Co-Operative Learning Method in Improving Cognitive Skills among Medical Students. Int.J.Curr.Microbiol.App.Sci. 6(3): 164-173.

doi: https://doi.org/10.20546/ijcmas.2017.603.018 